\title{
Numerical Models in Coastal Hazards and Coastal Environment
}

\author{
Han Soo Lee ${ }^{1, *} \mathbb{0}$, Young-Jin Choi ${ }^{2}$ and Seung-Buhm Woo ${ }^{3}$ \\ 1 Transdisciplinary Science and Engineering Program, Graduate School of Advanced Science and Engineering, \\ Hiroshima University, 1-5-1 Kagamiyama, Higashi-Hiroshima 739-8529, Hiroshima, Japan \\ 2 GeoSystem Research Corporation, 172 LS-ro, Gunpo-si 15807, Korea; yjchoi@geosr.com \\ 3 Department of Ocean Science, Inha University, Incheon 402-751, Korea; sbwoo@inha.ac.kr \\ * Correspondence: leehs@hiroshima-u.ac.jp; Tel.: +81-82-424-4405
}

check for

updates

Citation: Lee, H.S.; Choi, Y.-J.; Woo, S.-B. Numerical Models in Coastal Hazards and Coastal Environment. J. Mar. Sci. Eng. 2021, 9, 494. https:// doi.org/10.3390/jmse9050494

Academic Editor: Tony Clare

Received: 25 April 2021

Accepted: 1 May 2021

Published: 2 May 2021

Publisher's Note: MDPI stays neutral with regard to jurisdictional claims in published maps and institutional affiliations.

Copyright: (c) 2021 by the authors. Licensee MDPI, Basel, Switzerland. This article is an open access article distributed under the terms and conditions of the Creative Commons Attribution (CC BY) license (https:// creativecommons.org/licenses/by/ $4.0 /)$.
According to the United Nations (UN) Atlas of the Oceans, about $44 \%$ of the world's population lives in coastal areas within $150 \mathrm{~km}$ of the sea. On the other hand, coastal regions are constantly exposed to natural hazards such as storm surge, storm waves, and coastal floods, and inundations due to tropical cyclones and storms, as well as tsunamis due to underwater earthquakes, volcanic eruptions, and landslides. To strengthen resilience and adaptive capacity to climate related hazards and natural disasters and to make the human settlement more safe, resilient, and sustainable, as envisaged by the United Nations as the 13th and 11th Sustainable Development Goals (SDGs) [1], it is not possible to reproduce, evaluate, and predict those natural hazards without understanding the physical processes of the hazards and their interaction with human settlements.

Numerical models for coastal hazards and the coastal environment are important and essential tools for the prediction and estimation of those coastal hazards [2], and for the evaluation of their impacts on coastal morphodynamics, coastal lagoons, and wetlands, as well as the built-in environment in coastal zone.

The main scope of this Special Issue, therefore, has been to collect and demonstrate numerical models and their applications to various coastal hazards and coastal environment related issues. After rigorous review processes, twelve papers are included in the Special Issue. Their thematic contributions are described in the following.

Tsunamis are giant waves caused by earthquakes or volcanic eruptions under the sea and do not dramatically increase in height out in the depths of the ocean. However, as the waves propagate onto the coastal zone and inland, their heights increase as the depth of the ocean decreases. In Pattiaratchi [3], the influence of ocean topography such as seamounts, ridges, and plateaus on tsunami propagation in Western Australia was investigated by idealized tsunamigenic earthquakes with the MOST (method of splitting tsunami) model based on the non-linear shallow-water wave equations in spherical coordinates. In terms of storm surges, Liu et al. [4] showed the annual exceedance probability of water levels and wave heights along the Long Island Sound using the high-resolution coupled wave-circulation model (FVCOM-SWAVE) for flood risk assessments, and Smolders et al. [5] illustrated the effects of a hybrid nature-based and engineered flood defense system in storm surge attenuation in the Scheldt estuary with TELEMAC-3D based on the three-dimensional Reynolds averaged Navier-Stokes equations. In another application of numerical models in coastal zone, Lee et al. [6] investigated the effects of tidal currents, wind, and waves on the movement of oil spilled during the Hebei Spirit oil spill accident off the west coast of South Korea using the environmental fluid dynamic code (EFDC) model for 3D circulation, solving the three-dimensional, vertically hydrostatic, free surface, turbulent averaged equations of motion and simulating waves nearshore (SWAN) for waves. For coastal structures such as dikes and seawalls, the stability of the structures during hazard events is of importance in flood risk assessment and management. Silarom and Yamamoto [7] investigated the scour of coastal structures and outflow of backfilling materials of the structure in Thailand and Japan using numerical modelling with 
CADMAS-SURF by solving the continuity equation, Navier-Stokes equations of motion, and the volume of fluid technique for free surface and hydraulic model experiments, and found good agreement between the results of numerical modelling and hydraulic model experiments.

In another application of the numerical model in coastal and ocean environment, Lee et al. [8] demonstrated a self-burial mechanism of subsea pipelines with spoilers under steady flow conditions by applying a two-dimensional Navier-Stokes solver and comparing with the results of hydraulic model experiments.

Storm surges induced by tropical cyclones are one of main coastal hazards, as described; therefore understanding the role of breaking waves in near-surface mixing and tropical cyclone-induced vertical mixing in the oceanic boundary layer is of importance in hindcast and forecast of tropical cyclones and ensuing storm surges for coastal risk assessment and management. Hong et al. [9] evaluated the wave effects on upper-ocean mixing in the northern East China Sea in summer by analyzing the results of comparative numerical experiments: a stand-alone ocean model as a control run and two ocean-wave coupled models that include the effect of the breaking waves (BW) and of the wave-current interaction (WCI) with a vortex-force formalism. They applied a coupled ocean-wave model with regional ocean modeling system (ROMS) for ocean by solving the NavierStokes equations with hydrostatic and Boussinesq approximation and SWAN for waves. Kim and Moon [10] investigated the effect of the Mellor-Yamada turbulence model on tropical cyclone-induced vertical mixing in the oceanic boundary layer, and implemented an improved Mellor-Yamada turbulence model in the Research Institute for Applied Mechanics (RIAM) Ocean Model based on a three-dimensional, z-coordinate, and primitive equation with hydrostatic and the Boussinesq approximation. From the results of numerical experiments during the passage of Typhoon Maemi in 2003, they found the improved Mellor-Yamada turbulence model showed better agreement with satellite measurements resulting in sea surface temperature decrease and the mixed layer deepening compared with those from the original Mellor-Yamada turbulence model.

Numerical models for coastal environments were also applied in the ocean renewable energy field to assess the wave energy resources in the Korean seas and to estimate windinduced currents in the Gulf of California and their impact on tidal energy devices. Eum et al. [11] performed long-term wind wave hindcast modelling from 2007 to 2018 with marine surface winds from three different reanalysis datasets to assess the wave energy potential in the Korean seas and found higher wave energy potential in winter than in summer with particular effects of typhoons in August. Gross and Magar [12] applied a 3D shallow water equation model forced by tides and the meteorological conditions generated by Hurricane Odile to simulate the wind-induced current in the Gulf of California and the implications on site selection and risk of damage on tidal current power devices during extreme events.

In this Special Issue, the impacts of climate change are also compiled in terms of seasonal shoreline changes and sea-level rise. Based on the updated relative sea-level rise rates, 21st century sea-level rise projections are made for the west coast of Portugal Mainland by Antunes [13], with sea-level records from tide gauges and North Atlantic satellite altimetry data based on different empirical projections for national coastal planning and management for erosion and flooding. Hilton et al. [14] demonstrated the prediction of seasonal shoreline changes in Perranporth, United Kingdom, using the shoreline prediction model (ShoreFor) with synthesized wave forcing informed with and without relevant climate indices in the synthetic wave generation. They highlighted that using climate patterns to inform shoreline change models can improve shoreline predictions with the importance of selecting an appropriate index for the beach location.

Author Contributions: All authors; writing_original draft preparation, review, editing, and agreed to the published version of the manuscript. All authors have read and agreed to the published version of the manuscript. 
Funding: This research received no external funding.

Institutional Review Board Statement: Not applicable.

Informed Consent Statement: Not applicable.

Data Availability Statement: No new data were created or analyzed in this study.

Conflicts of Interest: The authors declare no conflict of interest.

\section{References}

1. Leadership Council of the Sustainable Development Solution Network. Indicators and a Monitoring Framework for the Sustainable Development Goals; Leadership Council of the Sustainable Development Solution Network: New York, NY, USA, 2015 ; Volume 233.

2. Lee, H.S.; Shimoyama, T.; Popinet, S. Impacts of tides on tsunami propagation due to potential Nankai Trough earthquakes in the Seto Inland Sea, Japan. J. Geophys. Res. Ocean. 2015, 120, 6865-6883. [CrossRef]

3. Pattiaratchi, C. Influence of Ocean Topography on Tsunami Propagation in Western Australia. J. Mar. Sci. Eng. 2020, 8, 629. [CrossRef]

4. Liu, C.; Jia, Y.; Onat, Y.; Cifuentes-Lorenzen, A.; Ilia, A.; McCardell, G.; Fake, T.; O’Donnell, J. Estimating the Annual Exceedance Probability of Water Levels and Wave Heights from High Resolution Coupled Wave-Circulation Models in Long Island Sound. J. Mar. Sci. Eng. 2020, 8, 475. [CrossRef]

5. Smolders, S.; João Teles, M.; Leroy, A.; Maximova, T.; Meire, P.; Temmerman, S. Modeling Storm Surge Attenuation by an Integrated Nature-Based and Engineered Flood Defense System in the Scheldt Estuary (Belgium). J. Mar. Sci. Eng. 2020,8 , 27. [CrossRef]

6. Lee, K.-H.; Kim, T.-G.; Cho, Y.-H. Influence of Tidal Current, Wind, and Wave in Hebei Spirit Oil Spill Modeling. J. Mar. Sci. Eng. 2020, 8, 69. [CrossRef]

7. Silarom, K.; Yamamoto, Y. The Reproduction Ability of a Numerical Model for Simulating the Outflow Rate of Backfilling Materials from a Coastal Structure. J. Mar. Sci. Eng. 2019, 7, 447. [CrossRef]

8. $\quad$ Lee, W.-D.; Jo, H.-J.; Kim, H.-S.; Kang, M.-J.; Jung, K.-H.; Hur, D.-S. Experimental and Numerical Investigation of Self-Burial Mechanism of Pipeline with Spoiler under Steady Flow Conditions. J. Mar. Sci. Eng. 2019, 7, 456. [CrossRef]

9. Hong, J.-S.; Moon, J.-H.; Kim, T. Effect of Breaking Waves on Near-Surface Mixing in an Ocean-Wave Coupling System under Calm Wind Conditions. J. Mar. Sci. Eng. 2020, 8, 540. [CrossRef]

10. Kim, T.; Moon, J.-H. Impact of Improved Mellor-Yamada Turbulence Model on Tropical Cyclone-Induced Vertical Mixing in the Oceanic Boundary Layer. J. Mar. Sci. Eng. 2020, 8, 497. [CrossRef]

11. Eum, H.-S.; Jeong, W.-M.; Chang, Y.S.; Oh, S.-H.; Park, J.-J. Wave Energy in Korean Seas from 12-Year Wave Hindcasting. J. Mar. Sci. Eng. 2020, 8, 161. [CrossRef]

12. Gross, M.; Magar, V. Wind-Induced Currents in the Gulf of California from Extreme Events and Their Impact on Tidal Energy Devices. J. Mar. Sci. Eng. 2020, 8, 80. [CrossRef]

13. Antunes, C. Assessment of Sea Level Rise at West Coast of Portugal Mainland and Its Projection for the 21st Century. J. Mar. Sci. Eng. 2019, 7, 61. [CrossRef]

14. Hilton, D.; Davidson, M.; Scott, T. Seasonal Predictions of Shoreline Change, Informed by Climate Indices. J. Mar. Sci. Eng. 2020, 8, 616. [CrossRef] 